\title{
QUEEN'S
UNIVERSITY
BELFAST
}

\section{Defining cachexia in a renal population}

Reid, J., Noble, H., Davenport, A., Farrington, K., Fouque, D., Porter, S., Seres, D., Shields, J., Slee, A., Witham, M. D., Wright, M., \& Maxwell, A. P. (2015). Defining cachexia in a renal population. Journal of Renal Care, 41(2), 79-80. https://doi.org/10.1111/jorc. 12129

\section{Published in:}

Journal of Renal Care

\section{Document Version:}

Peer reviewed version

Queen's University Belfast - Research Portal:

Link to publication record in Queen's University Belfast Research Portal

\section{Publisher rights}

() 2015 European Dialysis and Transplant Nurses Association/European Renal Care Association

This is the peer reviewed version of the following article: Reid J, Noble H, Davenport A, Farrington K, Fouque D, Porter S, Seres D, Shields J, Slee A, Witham M.D., Wright M, Maxwell A.P... (2015). DEFINING CACHEXIA IN A RENAL POPULATION. Journal of Renal Care 41(2), 79-80, which has been published in final form at http://onlinelibrary.wiley.com/doi/10.1111/jorc.12129/abstract. This article may be used for non-commercial purposes in accordance with Wiley Terms and Conditions for Self-Archiving."

\section{General rights}

Copyright for the publications made accessible via the Queen's University Belfast Research Portal is retained by the author(s) and / or other copyright owners and it is a condition of accessing these publications that users recognise and abide by the legal requirements associated with these rights.

Take down policy

The Research Portal is Queen's institutional repository that provides access to Queen's research output. Every effort has been made to ensure that content in the Research Portal does not infringe any person's rights, or applicable UK laws. If you discover content in the Research Portal that you believe breaches copyright or violates any law, please contact openaccess@qub.ac.uk. 


\section{Defining cachexia in a renal population}

Joanne Reid ${ }^{1}$, Helen Noble ${ }^{1}$, Andrew Davenport ${ }^{2}$, Ken Farrington ${ }^{3}$, Denis Fouque ${ }^{4}$, Sam Porter ${ }^{1}$, David Seres ${ }^{5}$, Joanne Shields ${ }^{6}$, Adrian Slee ${ }^{7}$, Miles D Witham ${ }^{8}$, Mark Wright $^{9}$, Alexander P. Maxwell ${ }^{1,6}$.

${ }^{1}$ Queen's University Belfast, UK. ${ }^{2}$ Royal Free Hospital, UK. ${ }^{3}$ East and North Hertfordshire Trust, UK. ${ }^{4}$ Université de Lyon, France. ${ }^{5}$ Columbia University New York, USA. ${ }^{6}$ Belfast Health \& Social Care Trust, UK. ${ }^{7}$ Anglia Ruskin University, UK. ${ }^{8}$ University of Dundee, UK. ${ }^{9}$ Leeds Teaching Hospitals Trust.

Corresponding author details: j.reid@qub.ac.uk

Cachexia is "a complex metabolic syndrome associated with underlying illness and characterised by muscle loss, with or without loss of fat" (Evans et al. 2008). It is a common syndrome associated with chronic illness and has been variably defined. One working definition of cachexia incorporates weight loss of at least $5 \%$ within $\leq 12$ months or $\mathrm{BMI}<20 \mathrm{~kg} / \mathrm{m}^{2}$ plus three of the following five features: decreased muscle strength; fatigue; anorexia; low fat-free mass index; abnormal biochemistry (increased inflammatory markers [CRP, IL-6], anaemia [ $\mathrm{Hb}<120 \mathrm{~g} / \mathrm{L}]$, low serum albumin [<32g/L] (Evans et al., 2008). Currently, there is no standardised treatment available for cachectic patients and the presence of the cachectic syndrome, associated with any chronic disease trajectory, increases mortality (Von Haeling \& Anker, 2010). Cachexia is present in a range of chronic illness including: cancer; cardiac disease; kidney disease and AIDS. Most work on the key features of cachexia has been in cancer (Fearon et al. 2011).

To date, limited attention has been devoted to cachexia in other chronic disorders such as chronic kidney disease (CKD) (Mak et al. 2011). For renal cachexia there are no standardised definitions or inclusion criteria to help inform practice or research (Reid et al. 2013). The importance of identifying the disease specific key features of cachexia is evident in the cancer population, where such work has allowed the biopsychosocial impact of this syndrome to be researched and potential therapeutic inventions trialled (Reid, 2014). The impact of cachexia in the renal population may parallel that in cancer, but to date research ascertaining this is lacking. 
Can we simply assume that the same diagnostic criteria and prognostic data apply in renal populations as in others such as cancer and heart failure? To do so without careful research would be inadvisable. Several features associated with CKD, e.g. proteinuria and renal anaemia, mean that some diagnostic criteria may reflect renal disease per se, rather than the cachectic state. Measures of fatigue, anorexia and low muscle mass may be impacted by alterations in biochemistry due to kidney failure, but also by treatment for CKD (e.g. dialysis). These uncertainties mean that studies to validate the definition and prognosis of cachexia specifically in renal populations are essential. Cachexia is known to be a polysymptomatic syndrome making an exact diagnosis difficult. Furthermore, symptoms commonly associated with cachexia, such as anorexia and fatigue, can be present in individuals without cachexia. More research is needed to establish if cachexia is a single well defined entity in patients with CKD and if so to define the characteristic symptoms, signs and biochemical features of cachexia in the renal population.

The clinical management of cachexia in persons with CKD is challenging (Mak et al. 2011) partly due to the difficulty discriminating cachexia from other causes of malnutrition. Indeed, the term malnutrition should probably be avoided in cachexia as it suggests that the primary problem is failure of nourishment. This implies that cachexia can be corrected by overcoming problems with absorption or by use of nutritional supplements. For persons with CKD there is now a greater emphasis on defining clinical markers for Protein Energy Wasting (PEW) which precedes cachexia and specialised diagnostic tools are being developed and tested (Cuppari et al. 2014). Cachexia is seen as a severe form of PEW (Fouque, 2008; Jadeja \& Kher, 2012), however it is still important to be able to clinically differentiate between cachexia and PEW as each state may require distinct management strategies. An ability to accurately discriminate between renal cachexia and PEW may also be important when defining target groups for future trials of novel pharmacological or nutritional interventions.

In an attempt to define cachexia in patients with CKD, a working group was established and met at the British Renal Society conference in Glasgow 2014. This initial workshop invited key health care professionals from the United Kingdom 
interested in cachexia and its management in CKD. Discussion focused on Evans' (2008) work and its appropriateness for a renal population. It was agreed that defining cachexia in CKD required further exploratory work to enable refinement of key defining characteristics. A subsequent workshop was held in Northern Ireland (in 2014) in order to engage health care professionals, academics and service users in an attempt to improve understanding of cachexia in renal disease. The workshop included guest lectures from: Professor Denis Fouque (Professor of Nephrology and Director of the Clinical Renal Unit, Université de Lyon, France); Dr David Seres (Director, Medical Nutrition, Associate Professor of Medicine in the Institute of Human Nutrition Department of Medicine, Columbia University USA); and Dr Damian Fogarty (Consultant Nephrologist Belfast Trust and previous Chairman, UK Renal Registry). Representatives from both the British Kidney Patient Association and Northern Ireland Kidney Patient Association also attended this workshop. These workshops have reinforced the need to further refine the definition of renal cachexia and how it differs from PEW and malnutrition. The urgent need to conduct epidemiological work to determine the key defining characteristics of cachexia in renal disease was emphasised.

In summary, there remains limited consensus on the defining characteristics of renal cachexia partly due to limited epidemiological research on this syndrome in CKD. There is a pressing need to robustly define the inclusion and exclusion criteria for renal cachexia to help target future research of this syndrome and its optimum therapy. 


\section{References}

Cuppari L, Meireles MS, Ramos Cl, et al. (2014) Subjective global assessment for the diagnosis of protein-energy wasting in nondialysis-dependent chronic kidney disease patients. Journal of Renal Nutrition. 24(6):385-9.

Evans WJ, Morley JE, Argilés J, et al. (2008). Cachexia, a new definition. Clinical Nutrition. 27:793-799.

Fearon K, Strasser F, Anker SD, et al. (2011) Definition and classification of cancer cachexia: an international consensus. The Lancet Oncology. 12 (5):489-95

Fouque D, Kalantar-Zadeh K, Kopple J, et al. (2008) A proposed nomenclature and diagnostic criteria for protein-energy wasting in acute and chronic kidney disease. Kidney International. 73:391-8.

Jadeja YP \& Kher V. (2012) Protein energy wasting in chronic kidney disease: An update with focus on nutritional interventions to improve outcomes. Indian Journal Endocrine Metabolism. 16:246-51.

Mak RH, Ikizler AT, Kovesdy CP, et al. (2011) Wasting in chronic kidney disease. Journal of Cachexia Sarcopenia and Muscle. 2:9-25.

Reid J (2014) Psychosocial, educational and communicative interventions for patients with cachexia and their family carers. Current Opinion in Supportive Palliative Care.8(4):334-8.

Reid J, Noble H, Porter S, et al. (2013) A literature review of chronic kidney disease and cachexia: understanding experience to inform evidence based health care. Journal of Renal Care. 39(1): 47-51.

von Haehling S \& Anker SD. (2010). Cachexia as a major underestimated and unmet medical need, facts and numbers. Journal of Cachexia Sarcopenia and Muscle. 1(1):1-5. 